\title{
Identifikasi Isolat Ekstrak Etanol Kulit Batang Rhizophora apiculata Blume dan Rhizophora mucronata Lam Serta Sitotoksisitasnya Terhadap Sel MCF-7 dan T47D
}

\section{Identification of Ethanol Extract Isolate of Rhizophora apiculata Blume and Rhizophora mucronata Lam Stem Bark and Their Cytotoxicity on MCF-7 and T47D Cells}

\author{
Joko Kristianto ${ }^{1}$, Haryoto Haryoto ${ }^{1,2}$, Peni Indrayudha ${ }^{1,2 *}$ \\ ${ }^{1}$ Program Studi Magister Farmasi, Sekolah Pasca Sarjana, Universitas Muhammadiyah Surakarta, \\ Jl. A. Yani Tromol Pos I Pabelan Sukoharjo 57162, Indonesia \\ ${ }^{2}$ Fakultas Farmasi, Universitas Muhammadiyah Surakarta, \\ Jl. A. Yani Tromol Pos I, Pabelan Kartasura, Sukoharjo 57162, Indonesia \\ *E-mail: peni.indrayudha@ums.ac.id
}

Received: 06 Juni 2020; Accepted: 17 Juni 2021; Published: 30 Juni 2021

\begin{abstract}
Abstrak
Tanaman mangrove sebagai obat tradisional telah lama digunakan oleh masyarakat untuk terapi penyakit antikanker. Tumbuhan mangrove belum banyak diteliti potensinya sebagai antikanker. Ekstrak metanol kulit batang $R$. mucronata diketahui memiliki aktivitas sitotoksik pada sel Myeloma. Penelitian ini bertujuan untuk menentukan isolat dari fraksi Etil asetat ekstrak metanol kulit batang $R$. mисronata dan $R$. apiculata dan mengkaji potensi aktivitas sitotoksik terhadap sel MCF-7 dan T47D. Serbuk kulit batang $R$. mucronata dan $R$. apiculata diekstraksi dengan metanol dengan cara maserasi kemudian ekstrak metanol difraksinansi berturut-turut dengan n-heksana, etil asetat, dan metanol. Fraksi etil asetat kemudian dipurifikasi dengan Kromatografi Kolom Tekan (KKT) dengan diameter $2 \mathrm{~cm}$ dan tinggi $30 \mathrm{~cm}$ dengan fase diam berupa Silica Gel $60(0,063-0,2 \mathrm{~mm})$ Merck 7734 dan eluen n-heksana:etil asetat (6:4, 5:5, 6:4, 7:3, 8:2, 9:1) dan n-heksana:metanol (9,5:0,5) masing-masing $10 \mathrm{ml}$. Eluat yang menghasilkan jumlah dan pola noda yang sama digabungkan menjadi satu isolat. Selanjutnya eluat diuapkan pada suhu kamar. Kemudian hasil purifikasi dari ekstrak $R$, mucronata diisolasi menggunakan KLT preparatif dengan fase diam silika gel GF254 0,25 mm dan fase gerak n-heksan:etil asetat (6:4), sedangkan ekstrak R. apiculata dengan fase gerak n-heksan:etil asetat (5:5). Hasil pemisahan noda senyawa dikerok dan dipisahkan dari fase diam menggunakan pelarut. Senyawa isolat dicek kemurnian menggunakan KLT fase diam silika gel GF254 0,25 mm. Hasil uji kualitatif fraksi etil asetat kulit batang $R$. apiculata tersebut dengan spektrofotometer NMR terdapat senyawa cis-3-(3,5-dihidroksifenil) akrilik acid, sedangkan fraksi Etil asetat kulit batang R.mucronata terdapat senyawa n-heksan-3-ol. Uji sitotoksisitas ekstrak etanol, fraksi nheksana, fraksi etil asetat dan ekstrak etanol dilakukan terhadap sel MCF-7 dan T47D dengan metode MTT. Hasil penelitian bahwa ekstrak etanol, fraksi n-heksana, fraksi etil asetat dan fraksi etanol dari ekstrak etanol kulit batang $R$. mucronata dan $R$. apiculata berdasar aktifitas sitotoksik tidak aktif terhadap sel MCF-7 dan T47D.
\end{abstract}

Kata Kunci: Isolat aktif, $R$. mucronata, R. apiculata, sitotoksik, sel MCF-7 dan T47D

\begin{abstract}
Mangrove plants as traditional medicine have long been used by the society for the therapy of anticancer diseases. So far, the potency of mangrove plants as anticancer has not been studied intensively. The methanol extract of $R$. mucronata stem bark has cytotoxic activity on myeloma cells. This study aims to determine the isolates of the ethyl acetate fraction of the methanol extract of the stem bark of $R$. mucronata and $R$. apiculata, and to examine the potency of cytotoxic activity against MCF-7 and T47D cells. The powder of the stem bark of $R$. mucronata and $R$. apiculata were extracted with methanol by maceration, and then the methanol extract was fractionated consecutively using $n$-hexane, ethyl acetate, and methanol. Ethyl acetate fraction was then purified by column chromatography with a diameter of $2 \mathrm{~cm}$ and a height of $30 \mathrm{~cm}$ with a static phase in the form of silica gel $60(0.063-0.2 \mathrm{~mm})$ Merck 7734 and eluent $\mathrm{n}$ hexane:ethyl acetate (6: 4, 5: 5, 6: 4, 7: 3, 8: 2, 9:1) and n-hexane: methanol (9,5: 0,5) $10 \mathrm{ml}$ each. The
\end{abstract}


eluates that produce the same number and pattern of stains were combined into one isolate. Then the eluate was evaporated at room temperature. Then the purification results of the extract $R$. mucronata were isolated using preparative TLC with $0.25 \mathrm{~mm}$ GF254 silica gel as static phase and n-hexane mobile phase: ethyl acetate (6: 4), while the apiculata extract with n-hexane mobile phase: ethyl acetate (5: 5). The results of the stain separation of the compound were scraped off and separated from the static phase using a solvent. The purity of isolates compound was examined using TLC in the static phase of silica gel GF254 $0.25 \mathrm{~mm}$. The qualitative test results of the ethyl acetate fraction of R. apiculata stem bark with an NMR spectrophotometer showed a composition of cis-3-(3,5-dihydroxyphenyl) acrylic acid, while the ethyl acetate fraction of $R$. mucronata stem bark contained n-hexan-3-ol compounds. The cytotoxicity test of ethanol extract, $n$-hexane fraction, ethyl acetate fraction and ethanol extract was carried out on MCF-7 and T47D cells using the MTT method. The results proved that the ethanol extract, $n$-hexane fraction, ethyl acetate fraction and ethanol fraction from the ethanol extract of $R$. mucronata and $R$. apiculata stem bark, based on cytotoxic activity, were inactive against MCF-7 and T47D cells.

Keywords: Active isolate, R. mucronata, R. apiculata, cytotoxic, MCF-7 and T47D cells

\section{PENDAHULUAN}

Angka kejadian penyakit kanker di Indonesia (136,2/ 100.000 penduduk) berada pada urutan 8 di Asia Tenggara, sedangkan di Asia urutan ke 23. Angka kejadian untuk perempuan yang tertinggi adalah kanker payudara yaitu sebesar 42,1 per 100.000 penduduk dengan rata-rata kematian 17 per 100.000 penduduk (Kemenkes RI, 2019).

Pembedahan dan radiasi dilakukan untuk mengobati penyakit kanker, namun terbatas pada kanker lokal stadium awal dan tidak efektif pada kanker stadium lanjut yang telah mengalami metastasis. Pengobatan kanker dengan obat (kemoterapi) hanya efektif untuk beberapa periode dan belum mampu memberikan hasil yang memuaskan. Oleh karena itu, pemilihan alternatif terapi yang aman, efektif dan selektif pada penyakit kanker sangat penting seperti penggunaan obat tradisional (Ma'at, 2003), terutama dari tumbuhan contohnya mangrove.

Tumbuhan mangrove sangat banyak tumbuh di daerah pesisir pantai. Sebagian besar dari tumbuhan mangrove belum banyak digunakan sebagai bahan obat. Namun ekstrak dan bahan mentah dari tumbuhan mangrove telah digunakan oleh masyarakat pesisir untuk keperluan pengobatan tradisional. Hutan mangrove di pantai Cilacap mencapai 15.145 hektar, dengan 17 jenis tumbuhan mangrove (Hadiyati, 2000) diantaranya Rhizophora sp.
Tumbuhan mangrove merupakan sumber bahan obat tradisional yang dapat digunakan sebagai sumber senyawa bioaktif di antaranya golongan tanin, saponin, terpenoid, alkaloid dan steroid sebagai antimikroba, antifungi, antivirus, antitumor, insektisida dan antileukemia. Bagian tumbuhan yang dapat digunakan sebagai antikanker adalah kulit batang, akar, daun, bunga dan buah. Senyawa metabolit sekunder sebagai senyawa komponen bioaktif yang ditemukan belum memberikan informasi mengenai senyawa yang paling berperan sebagai senyawa metabolit sekunder utama (Soetarno, 2000).

Hasil penelitian Harwoko (2010) menunjukkan bahwa fraksi n-heksana: kloroform dari ekstrak metanol kulit batang Rhizophora mucronata bersifat sitotoksik pada sel myeloma dengan nilai $\mathrm{IC}_{50}$ sebesar $15 \mu \mathrm{g} / \mathrm{mL}$ dan hasil uji kualitatif fraksi tersebut mengandung senyawa flavonoid dan terpenoid.

Hasil uji fotokimia ekstrak metanol pada kulit batang bakau positif mengandung alkaloid, flavonoid dan tanin. Tanin merupakan senyawa utama dari tumbuhan bakau Rhizophora apiculata yang diketahui dapat menangkal efek stres oksidatif yang disebabkan oleh radikal bebas (Berawi dan Marini, 2018)

Penelitian terhadap tanaman mangrove famili Rhizophora, di antaranya spesies $R$. apicullata dan $R$. mucronata belum banyak dilaporkan, terutama kajian senyawa 
kimianya yang berpotensi sebagai antikanker. Berdasarkan latar belakang tersebut di atas maka perlu dilakukan penelitian untuk melakukan penentuan isolat aktif dan aktivitas sitotoksisitas ekstrak etanol kulit batang $R$. apicullata dan $R$. mucronata sebagai antikanker melalui uji sitostoksik terhadap sel MCF-7 dan T47D.

\section{METODE PENELITIAN}

\section{Alat dan Bahan}

Alat uji yang digunakan timbangan analitik (Ohaus), mikropipet (Socorex), stirrer (Big Squid IKA Werke), oven, autoclave, homocytometer, rotary evaporator, inkubator $\mathrm{CO}_{2}$ (Binder), tangki nitrogen cair, Laminar Air Flow, 96-well plate, ELISA reader (Biotex ELx800), UV 254 nm dan UV 366 $\mathrm{nm}$, Spektroskopi NMR (Agilent $500 \mathrm{Mhz}$ ).

Bahan uji adalah serbuk kulit batang $R$. apiculata dan $R$. mucronata yang diperoleh dari Cilacap, etanol 96\%, n-heksana, etil asetat, sel T47D dan MCF7, RPMI (Rosewell Park Memorial Institue) 1640, DMEM, $\mathrm{NaHCO}_{3}$, DMSO $100 \%$, alkohol 80\%, tripsin 0,025\%, FBS 10\%, PBS (Phosphat Buffer Saline), larutan MTT (3-(4,5-dimetiltiazol-2il) difenil tetrazolium bromida) $0,5 \%$, larutan SDS (Sodium Dodesil Sulfat) 10\%, alumunium foil.

\section{Jalannya Penelitian}

Sampel kulit batang mangrove berasal dari Kawasan Konservasi Hutan Mangrove Kabupaten Cilacap. Kulit batang mangrove Rhizophora sebanyak $3 \mathrm{~kg}$ berat kering dihaluskan menggunakan blender, hingga diperoleh serbuk kulit batang mangrove.

\section{Ekstraksi}

Simplisia sebanyak $500 \mathrm{~g}$ diekstraksi secara maserasi menggunakan 2,5 L etanol 96\% selama 24 jam. Maserat kemudian disaring sehingga diperoleh filtrat dan residu. Residu diremaserasi dan diberi perlakuan yang sama selama 24 jam hari berikutnya sampai hari ketiga dan diperoleh filtrat berwarna bening. Filtrat ditampung dan dipekatkan menggunakan rotary evaporator suhu $50^{\circ} \mathrm{C}$ dengan kecepatan $250 \mathrm{rpm}$.

\section{Fraksinasi Ekstrak}

Fraksinasi dilakukan dengan partisi caircair. Sebanyak 50 gram ekstrak etanol kulit batang mangrove dilarutkan dalam $50 \mathrm{ml}$ etanol kemudian dipartisi dengan pelarut dimulai dari n-heksana $50 \mathrm{ml}$ dan etil asetat $50 \mathrm{ml}$. Fraksi yang didapatkan kemudian dipekatkan di atas cawan porselin.

\section{Isolasi Fraksi Etil asetat ekstrak kulit batang $R$. mucronata}

Fraksi Etil asetat ekstrak kulit batang $R$. mucronata dipurifikasi menggunakan kromatografi kolom tekan (KKT) dengan diameter $2 \mathrm{~cm}$ dan tinggi $30 \mathrm{~cm}$ dengan fase diam berupa silica gel $60(0,063-0,2 \mathrm{~mm})$ Merck 7734 dan eluen n-heksana:etil asetat $(6: 4,5: 5,6: 4,7: 3,8: 2,9: 1)$ dan n-heksana: metanol $(9,5: 0,5)$ masing-masing $10 \mathrm{~mL}$ dengan sistem elusi isokratik. Pemisahan dilakukan dengan mengamati pemisahan warna pada kolom dan menampung setiap pemisahan pada wadah dengan volume $10 \mathrm{ml}$. Hasil purifikasi dicek profil KLT dan dilihat pada UV $254 \mathrm{~nm}$ dan $365 \mathrm{~nm}$. Eluat yang sama digabungkan menjadi satu isolat. Selanjutnya isolate diuapkan pada suhu kamar.

Isolasi dilakukan dengan menggunakan KLT preparatif dengan fase diam silika gel GF254 0,25 $\mathrm{mm}$ dan fase gerak hasil optimasi. Hasil pemisahan noda senyawa dikerok dan dipisahkan dari fase diam menggunakan pelarut n-heksana:etil asetat (6:4). Senyawa isolat dicek kemurnian menggunakan KLT fase normal silika gel GF254 0,25 mm.

\section{Isolasi Fraksi Etil asetat ekstrak kulit batang $R$. apiculata}

Fraksi etil asetat ekstrak kulit batang $R$. apiculata dipurifikasi menggunakan kromatografi kolom tekan (KKT) dengan diameter $2 \mathrm{~cm}$ dan tinggi $30 \mathrm{~cm}$ dengan fase diam berupa silica gel $60(0,063-0,2 \mathrm{~mm})$ 
Merck 7734 dan eluen n-heksana:etil asetat $(6: 4,5: 5,6: 4,7: 3,8: 2,9: 1)$ dan n-heksana : metanol $(9,5: 0,5)$ dengan sistem elusi isokratik. Pemisahan dilakukan dengan mengamati pemisahan warna pada kolom dan menampung setiap pemisahan pada wadah dengan volume $10 \mathrm{~mL}$. Hasil sub fraksi dicek profil KLT dan dilihat pada UV $254 \mathrm{~nm}$ dan $365 \mathrm{~nm}$. Eluat yang sama digabungkan menjadi satu isolat. Selanjutnya isolat diuapkan pada suhu kamar.

Isolasi dilakukan dengan menggunakan KLT preparatif dengan fase diam silika gel GF254 0,25 $\mathrm{mm}$ dan fase gerak hasil optimasi. Hasil pemisahan noda senyawa dikerok dan dipisahkan dari fase diam menggunakan pelarut $\mathrm{n}$-heksana:etil asetat (5:5). Senyawa isolat dicek kemurnian menggunakan KLT fase normal silika gel GF254 0,25 mm.

\section{Identifikasi Isolat}

Indentifikasi dari hasil Isolasi fraksi etil asetat dianalisa menggunakan instrumen spektrofotometer Nuclear Magnetic Resonance $(\mathrm{NMR})=$ Agilent $500 \mathrm{MHz}$ dengan sistem konsol DD2, yang beroperasi pada frekuensi $500 \mathrm{MHz}(1 \mathrm{H})$ dan $125 \mathrm{MHz}$ (13C) di Laboratorium Kimia, Fakultas Matematika dan Ilmu Pengetahuan Alam, Institut Teknologi Bandung.

Spektrum ${ }^{1} \mathrm{H}-\mathrm{NMR}$ dan ${ }^{13} \mathrm{C}-\mathrm{NMR}$ hasil pengukuran dianalisis dengan mendeteksi lingkungan kimia, multiplikasi, rasio jumlah dan jarak antar inti atom berdasarkan momen magnetnya untuk memprediksi senyawa kimia pada sampel uji. Struktur ini dianalisa prediksi menggunakan software nmrdb.org sehingga diperoleh spektrum sesuai prediksi software.

\section{Penyiapan Kultur Sel MCF7 dan T47D}

Panen sel MCF7 dan T47D dilakukan jika sel sudah $80 \%$ konfluen. Sel dibuang medianya kemudian sel dicuci dengan PBS sebanyak 2 kali, dengan jumlah PBS yaitu 1/2 dari volume media awal. Kemudian ditambahkan Tripsin-EDTA (Tripsin 0,25\%) secara merata dan diinkubasi selama 3 menit. Selanjutnya media $\pm 5 \mathrm{~mL}$ ditambahkan untuk menghilangkan tripsin. Sel diamati di bawah mikroskop, untuk kemudian sel yang telah terpisah dimasukkan dalam conical steril baru (CCRC,2009).

\section{Uji Sitotoksik}

Suspensi sel MCF7 dalam medium DMEM dan sel T47D dalam medium RPMI masing-masing sebanyak $100 \mu \mathrm{L}$ dengan kepadatan $5 \times 10^{4}$ sel dimasukkan ke dalam plate 96 dan diinkubasi selama 24 jam dalam inkubator $\mathrm{CO}_{2} 5 \%$. Setelah kultur sel MCF-7 dan T47D diinkubasi selama 24 jam medianya dibuang, kemudian dilanjutkan dengan perlakuan sampel.

Kemudian $100 \mu \mathrm{L}$ sampel ditambahkan dalam medium pada tiap sumuran dengan seri konsentrasi ekstrak 15,625; 31,25; 62,5; 125 ; $250 \mu \mathrm{g} / \mathrm{mL}$ dan seri konsentrasi fraksi 7,81 ; 15,$625 ; 31,25 ; 62,5 ; 125 \mu \mathrm{g} / \mathrm{mL}$. Plate diinkubasi dalam inkubator $\mathrm{CO}_{2} 5 \%$ selama 24 jam pada suhu $37^{\circ} \mathrm{C}$. kontrol positif yang digunakan adalah doksorubisin.

Sebanyak $15 \mu \mathrm{L}$ MTT 0,5\% ditambahkan ke dalam PBS, kemudian diinkubasi selama 4 jam dalam inkubator $\mathrm{CO}_{2}$ pada suhu $37^{\circ} \mathrm{C}$. Sel hidup akan bereaksi dengan MTT membentuk formazan tidak larut yang berwarna ungu. Selanjutnya larutan stopper SDS dalam $\mathrm{HCl}$ $10 \%$ ditambahkan dan diinkubasi selama 2 jam jam pada suhu ruang. Serapan dari formazan dibaca dengan ELISA reader pada panjang gelombang $550 \mathrm{~nm}$. Persentase sel hidup dihitung dari data absorbansi. Kurva hubungan $\log$ konsentrasi versus log konsentrasi dibuat untuk menghitung nilai $\mathrm{IC}_{50}$ nya (CCRC, 2013).

\section{HASIL DAN PEMBAHASAN}

Identifikasi Isolat Fraksi Etil Asetat dari Ekstrak Etanol Kulit Batang $R$. apiculata

Senyawa hasil isolasi yang terdapat pada fraksi etil asetat ekstrak etanol kulit batang $R$. apiculata telah dilakukan penelusuran strukturnya menggunakan spektrofometer NMR dengan hasil spektrum ${ }^{1} \mathrm{H}-\mathrm{NMR}$ 
senyawa 1 dapat dilihat pada Gambar 1, sedangkan lingkungan kimia, multiplikasi, rasio jumlah dan jarak antar inti atom berdasarkan momen magnetnya dapat dilihat pada Tabel 1. Sinyal a merupakan proton pada cincin aromatik benzena yang muncul sebagai singlet $(s)$ menandakan proton ini tidak mempunyai proton tetangga non-ekivalen. Geseran kimianya (d) nya berada di daerah yang relatif upfield $(6.18 \mathrm{ppm})$ untuk rentang proton aromatik (6-8 ppm). Proton a ini kemungkinan sangat dekat dengan gugus pendonor elektron (electron donating group/ EDG) seperti $\mathrm{OH}$ yang mendonorkan elektronnya kepada proton a tersebut, sehingga lebih terlindungi terhadap medan magnet luar. Sinyal b sedikit banyak karakternya mirip dengan sinyal a, yaitu singlet dan berada di daerah yang relatif upfield untuk rentang proton aromatik. Namun, dibandingkan dengan proton a, proton b ini sedikit lebih downfield (6.40 ppm). Hal ini kemungkinan karena selain dekat dengan EDG seperti $\mathrm{OH}$, proton ini juga dekat dengan gugus penarik elektron (electron withdrawing group/ EWG) seperti ikatan rangkap maupun gugus $\mathrm{COOH}$. EWG akan menarik elektron dari proton tersebut dan membuatnya menjadi kurang terlindungi terhadap medan magnet luar (McMurry, 2010).

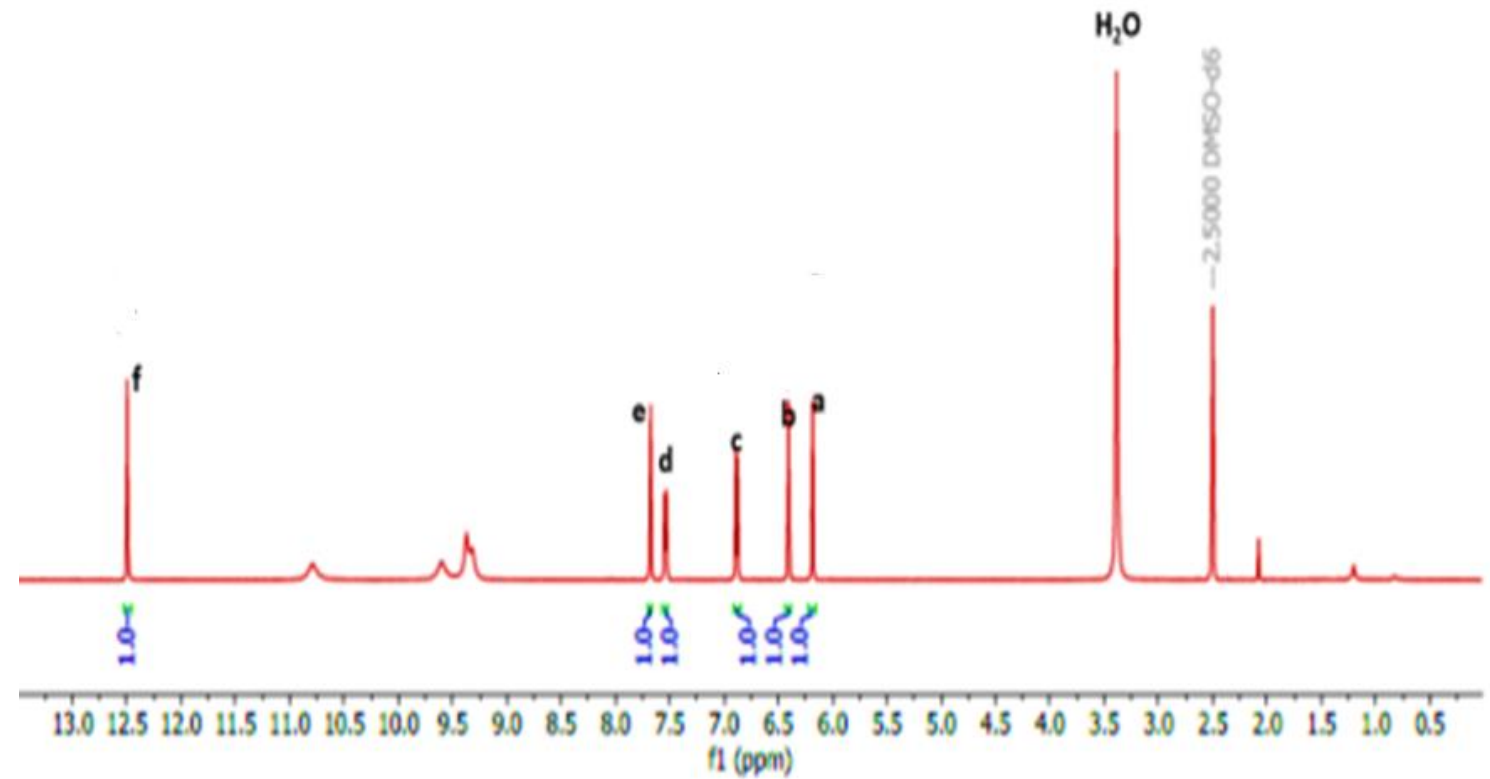

Gambar 1. Spektrum ${ }^{1}$ H-NMR senyawa 1 berdasar eksperimen

Tabel 1. Profil ${ }^{1} \mathrm{H}-\mathrm{NMR}$ dari senyawa 1

\begin{tabular}{ccccc}
\hline Sinyal & $\begin{array}{c}\mathbf{d} \\
(\mathbf{p p m})\end{array}$ & $\begin{array}{c}\text { Jumlah } \\
\text { proton }\end{array}$ & Multiplikasi & $\begin{array}{c}\text { J-Jcoupling constant } \\
(\mathbf{H z})\end{array}$ \\
\hline $\mathbf{a}$ & 6.18 & 1 & $s$ & - \\
$\mathbf{b}$ & 6.40 & 1 & $s$ & - \\
$\mathbf{c}$ & 6.88 & 1 & $d$ & 8.5 \\
$\mathbf{d}$ & 7.54 & 1 & $d$ & -6.6 \\
$\mathbf{e}$ & 7.67 & 1 & $s$ & - \\
$\mathbf{f}$ & 12.49 & 1 & $s$ & \\
\hline
\end{tabular}


Sinyal c muncul pada d yang lebih downfield (6.88 ppm) dibandingkan sinyal a dan b, kemungkinan proton ini berada di daerah yang lebih dekat dengan EWG yang kuat seperti ikatan rangkap vinilik, benzena atau $\mathrm{COOH}$ (Pavia et al., 2008). Sinyal c muncul sebagai puncak kembar (doublet/ $d$ ) mengindikasikan keberadaan 1 proton tetangga non-ekivalen. Sinyal d sepertinya merupakan pasangan dengan sinyal c. Sinyal d juga muncul sebagai doublet mengindikasikan adanya 1 proton tetangga non-ekivalen, namun d-nya lebih downfield (7,54 ppm) dibandingkan sinyal c. Hal ini kemungkinan proton d lebih dekat dengan EWG kuat dibandingkan proton c. Rasio proton $\mathbf{c}$ dan $\mathbf{d}$ adalah 1:1 mengindikasikan kedua proton punya jumlah yang sama. Berdasarkan $\mathrm{J}-\mathrm{J}_{\text {coupling constant, kedua proton (c }}$ dan d) merupakan proton vinilik yang mempunyai konfigurasi cis karena mempunyai $\mathrm{J}-\mathrm{J}_{\text {coupling constant }}$ sebesar 8,5 dan $8,6 \mathrm{~Hz}$. Proton vinilik yang mempunyai J$\mathrm{J}_{\text {coupling }}$ constant pada rentang $5-14 \mathrm{~Hz}$ mempunyai konfigurasi cis, sedangkan jika rentangnya $11-19 \mathrm{~Hz}$ mempunyai konfigurasi trans (Koyama et al., 1989).

Sinyal e merupakan proton aromatik yang paling downfield (7.67 ppm), mengindikasikan keberadaannya yang dekat dengan EWG. Proton ini mempunyai jumlah proton sebanyak 1 dan berbentuk singlet yang mengindikasikan ketiadaan proton tetangga non-ekivalen. Sinyal f merupakan proton yang paling downfield, tidak terlindungi dari medan magnet luar sehingga bergeser ke d $12.49 \mathrm{ppm}$. Proton di daerah ini biasanya merupakan proton $\mathrm{OH}$ pada gugus karboksilat $(\mathrm{COOH})$. Proton ini berjumlah satu dan berbentuk singlet karena tidak mempunyai proton tetangga non-ekivalen.

Hasil analisa berdasar spektrum ${ }^{1} \mathrm{H}-\mathrm{NMR}$ dan lingkungan kimia diperoleh hasil struktur senyawa 1 adalah cis-3-(3,5-dihidroksifenil) akrilik acid ditunjukkan pada gambar 2 . Lingkungan kimia senyawa 1 (cis-3-(3,5dihidroksifenil) akrilik acid memiliki kesesuaian dengan spektrum analisis prediksi setelah dianalisa menggunakan software (www.nmrdb.org) seperti pada Gambar 3 yang menunjukkan adanya gugus-gugus dan lingkungan kimia yang sama dengan senyawa 1.

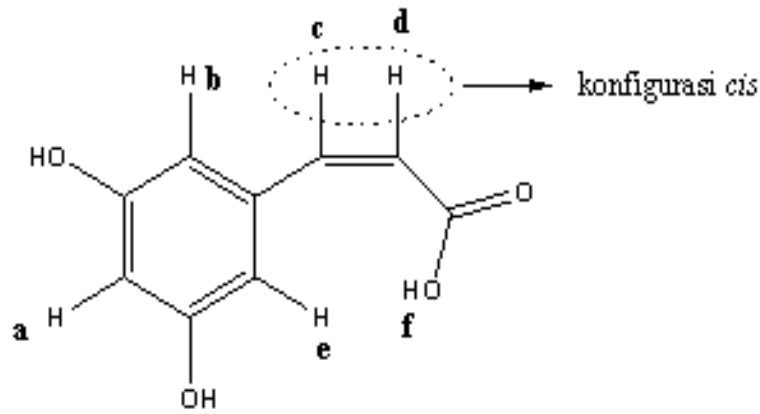

Gambar 2. Struktur molekul senyawa (cis-3(3,5-dihidroksifenil) akrilik acid

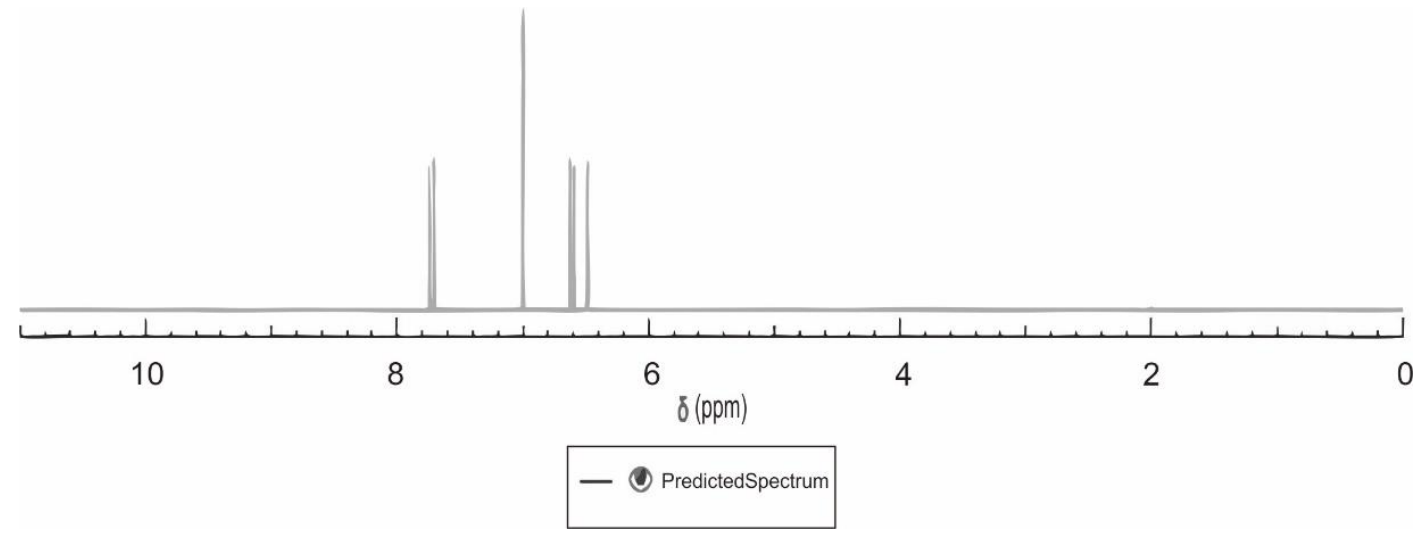

Gambar 3. ${ }^{1}$ H-NMR Senyawa 1 berdasarkan software prediksi (https://www.nmrdb.org/new_predictor/index.shtml?v=v2.115.0) 
Identifikasi Isolat Fraksi Etil Asetat dari Ekstrak Etanol Kulit Batang R.mucronata

Spektrum ${ }^{1} \mathrm{H}-\mathrm{NMR}$ untuk senyawa 2 terlihat cukup kompleks dengan banyaknya multiplikasi sinyal yang saling bertumpang tindih hal ini cukup mempersulit dalam menganalisisnya. Sehingga, untuk analisis struktur senyawa ini memungkinkan untuk dimulai menggunakan spektrum ${ }^{13} \mathrm{C}$-NMR terlebih dahulu. Spektrum ${ }^{13} \mathrm{C}$-NMR senyawa 2 dapat dilihat pada Gambar 4, sedangkan lingkungan kimia, inti atom berdasarkan momen magnetnya dapat dilihat pada Tabel 2.

Proton pada gugus fenol biasanya tidak muncul karena mudah mengalami polimerasi. Proton ini hanya muncul pada konsentrasi sampel yang sangat tinggi namun hanya berupa puncak tipis dan melebar pada d 3-7 ppm (Nerantzaki et al., 2011). Sinyal pada 2.5 ppm merupakan kontaminasi proton pada pelarut DMSO-D 6 yang digunakan, sedangkan sinyal pada 3.4 ppm adalah proton $\mathrm{H}_{2} \mathrm{O}$ yang juga merupakan kontaminasi pada pelarut deuterated yang bersifat sangat higroskopis (Jones et al., 2005).

Tabel 2. Profil lingkungan kimia ${ }^{13} \mathrm{C}-\mathrm{NMR}$ dari

\begin{tabular}{cc} 
& senyawa 2 \\
\hline Sinyal & d (ppm) \\
\hline a & 6,7 \\
b & 22,4 \\
c & 24,2 \\
d & 29,3 \\
e & 36,1 \\
f & 61,9
\end{tabular}

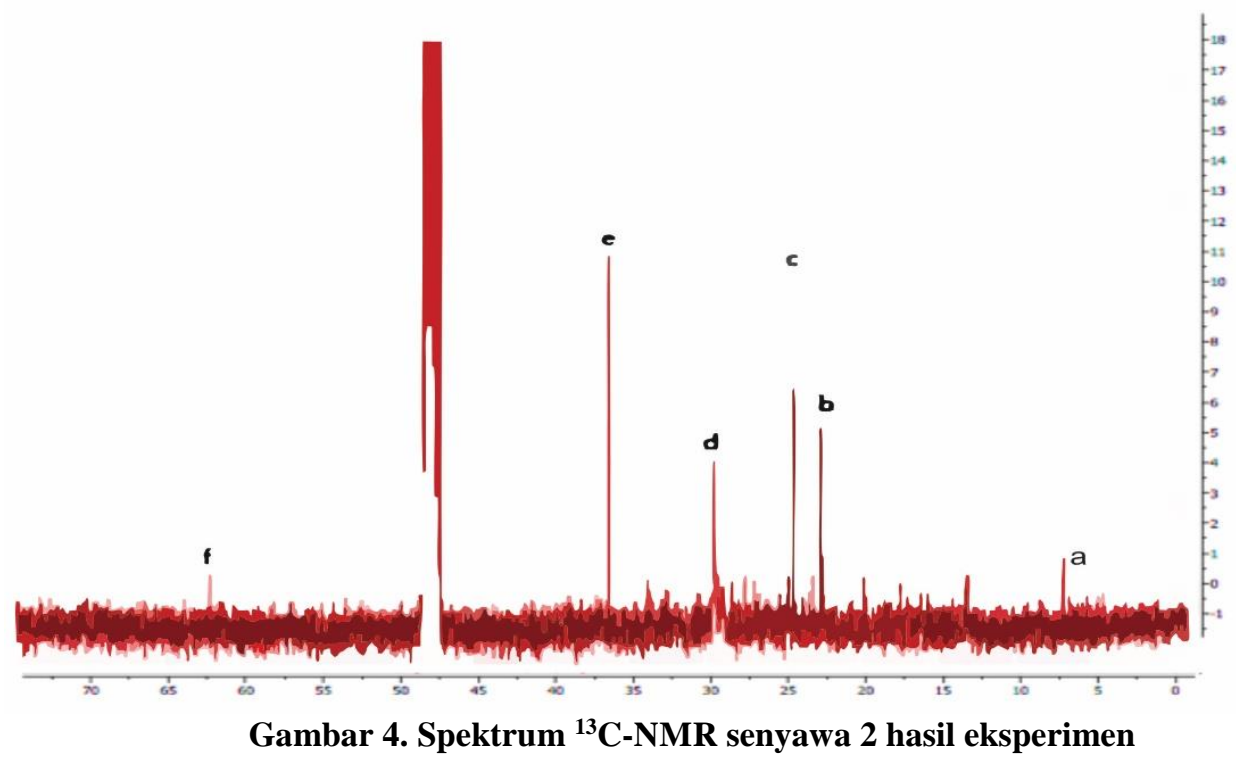

Informasi yang didapat dari spektrum ${ }^{13} \mathrm{C}-\mathrm{NMR}$ biasanya hanya berupa geseran kimia (d) mengingat ${ }^{13} \mathrm{C}$ kelimpahan di alam sangat kecil yaitu hanya $1,1 \%$ dan selebihnya adalah ${ }^{12} \mathrm{C}$. Sayangnya hanya ${ }^{13} \mathrm{C}$ yang mempunyai momen magnet dengan ${ }^{12} \mathrm{C}$ tidak mempunyai momen magnet. Hal ini menyebabkan ${ }^{13} \mathrm{C}$ tidak mengalami multiplikasi dan area serapannya tidak dapat dihitung rasio jumlah karbonnya (Ward, 1999).

Spektrum ${ }^{13}$ C-NMR pada Gambar 4 dan lingkungan kimia, multiplikasi, rasio jumlah dan jarak antar inti atom berdasarkan momen magnetnya pada Tabel 2 menunjukan sinyal a merupakan karbon yang paling upfield menyerap di 6.7 ppm diikuti sinyal b (22.4 ppm), c (24.2 ppm), d (29.3 ppm) dan e (36.1 
ppm). Karbon-karbon ini biasanya merupakan karbon rantai alkil yang mengalami pergeseran kimia seiring dengan kedekatannya dengan gugus yang elektronegatif seperti OH. Sinyal f merupakan karbon yang paling downfield (61.9 ppm) mengindikasikan karbon ini paling dekat dengan atom yang elektronegatif seperti $\mathrm{OH}$.

Data spektrum ${ }^{1} \mathrm{H}-\mathrm{NMR}$ senyawa 2 dan lingkungan kimia, multiplikasi, rasio jumlah dan jarak antar inti atom berdasarkan momen magnetnya dapat dilihat pada pada gambar 5 dan tabel 3, sinyal a dan b pada ${ }^{1} \mathrm{H}-\mathrm{NMR}$ mengindikasikan 2 tipe proton alkil yang mempunyai 2 proton tetangga non-ekivalen, karena muncul sebagai puncak triplet $(\mathrm{t})$. Proton ini cukup terlindungi (upfield) sehingga menyerap radiasi elektromagnetik pada berturut-turut 0.89 dan $0.96 \mathrm{ppm}$. Total jumlah proton keduanya adalan 6 yang ditunjukkan bilangan integrasi 1.3 dan 5.4 pada geseran kimia tersebut yang saling bertumpang tindih karena dekatnya geseran kimianya.

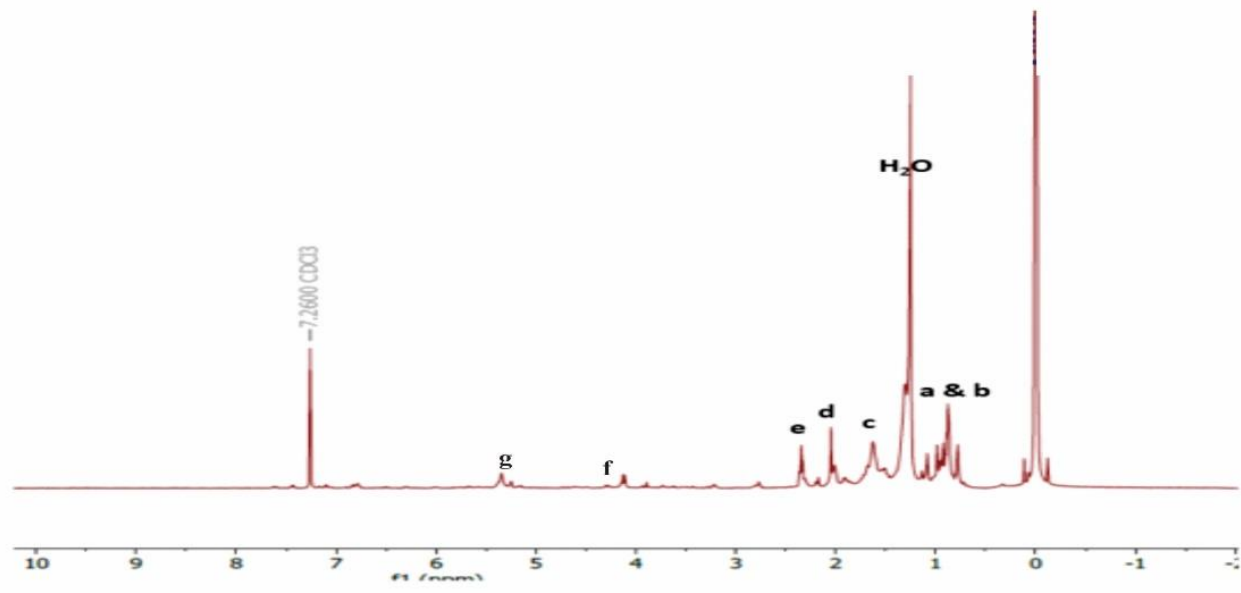

Gambar 5. Spektrum ${ }^{1}$ H-NMR senyawa 2 eksperimen

Tabel 3. Profil ${ }^{1}$ H-NMR dari senyawa 2

\begin{tabular}{cccc}
\hline Sinyal & d (ppm) & Jumlah proton & Multiplikasi \\
\hline a & 0,89 & 3 & $t$ \\
b & 0,96 & 3 & $t$ \\
c & 1,30 & 2 & $m$ \\
d & 2,17 & 2 & $m$ \\
e & 2,36 & 2 & $m$ \\
$\mathbf{f}$ & 4,12 & 1 & $m$ \\
g & 5,34 & 1 & $s$ \\
\hline
\end{tabular}

Sinyal c juga masih bertipe proton alifatik namun lebih dekat dengan atom elektronegatif daripada proton $\mathbf{a}$ dan $\mathbf{b}$ karena sedikit bergeser ke downfield (1,30 ppm). Proton ini mempunyai 5 proton tetangga nonekivalen sehingga muncul sebagai multiplet. Sinyal d dan e mempunyai karakter yang kurang lebih sama namun lebih downfield (berturut-turut 2,17 dan 2,36 ppm) dibandingkan proton c. Proton inipun lebih menyerupai multiplet yang agak sulit dispesifikasi meskipun secara teori, proton $\mathbf{d}$ seharusnya berbentuk kuartet karena mempunyai 3 proton tetangga non-ekivalen sedangkan proton e seharusnya berbentuk kuintet karena mempunyai 4 proton tetangga 
non-ekivalen. Untuk rasio jumlah proton pada proton c, d dan e tidak bisa dikuantifkasi dengan jelas karena saling bertumpang tindih, terutama dengan sinyal proton dari kontaminasi air pada pelarut $\mathrm{CDCl}_{3}$.

Sinyal f merupakan proton alkil yang paling dekat dengan atom elekronegatif sehingga bergeser cukup downfield (4.12 ppm). Proton ini mempunyai 4 proton tetangga non-ekivalen sehingga muncul sebagai multiplet. Jumlah proton ini tepat sesuai prediksi yaitu sebanyak 1 . Sinyal g merupakan proton $\mathrm{OH}$ alkohol yang menyerupai puncak melebar terserap pada radiasi 5.34 ppm karena inti $\mathrm{H}$ berada dalam keadaan tidak terlindungi oleh medan magnet luar. Proton ini muncul sebagai puncak singlet karena tidak mempunyai proton tetangga nonekivalen. Proton yang mengkontaminasi pelarut deutarated $\mathrm{CDCl}_{3}$ muncul pada 7.2 ppm.

Berdasarkan hasil analisis kombinasi antara ${ }^{1} \mathrm{H}-\mathrm{NMR}$ dan ${ }^{13} \mathrm{C}-\mathrm{NMR}$ pada senyawa 2 , maka struktur molekul tersebut adalah $n$ heksan-3-ol seperti yang diperlihatkan pada Gambar 6.

Lingkungan kimia senyawa 2 ( $n$-heksan3-ol) memiliki kesesuaian dengan spektrum ${ }^{13} \mathrm{C}-\mathrm{NMR}$ prediksi setelah dianalisa menggunakan software nmrdb.org seperti pada Gambar 7, spektrum ${ }^{1} \mathrm{H}-\mathrm{NMR}$ Senyawa 2 seperti pada Gambar 8 yang menunjukkan adanya gugus-gugus dan lingkungan kimia yang sama.

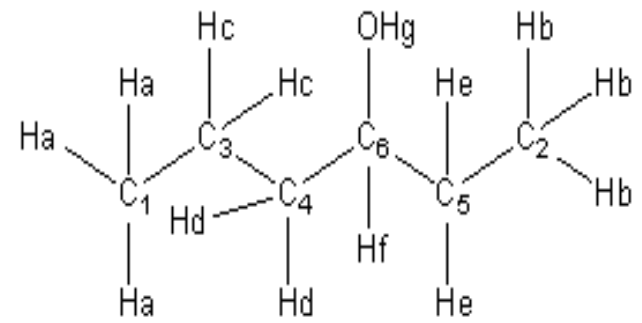<smiles>C=CCCC</smiles><smiles>CCCC(O)CC</smiles>

n-heksan-3-ol

Gambar 6. Struktur molekul senyawa 2 (n-heksan-3-ol)

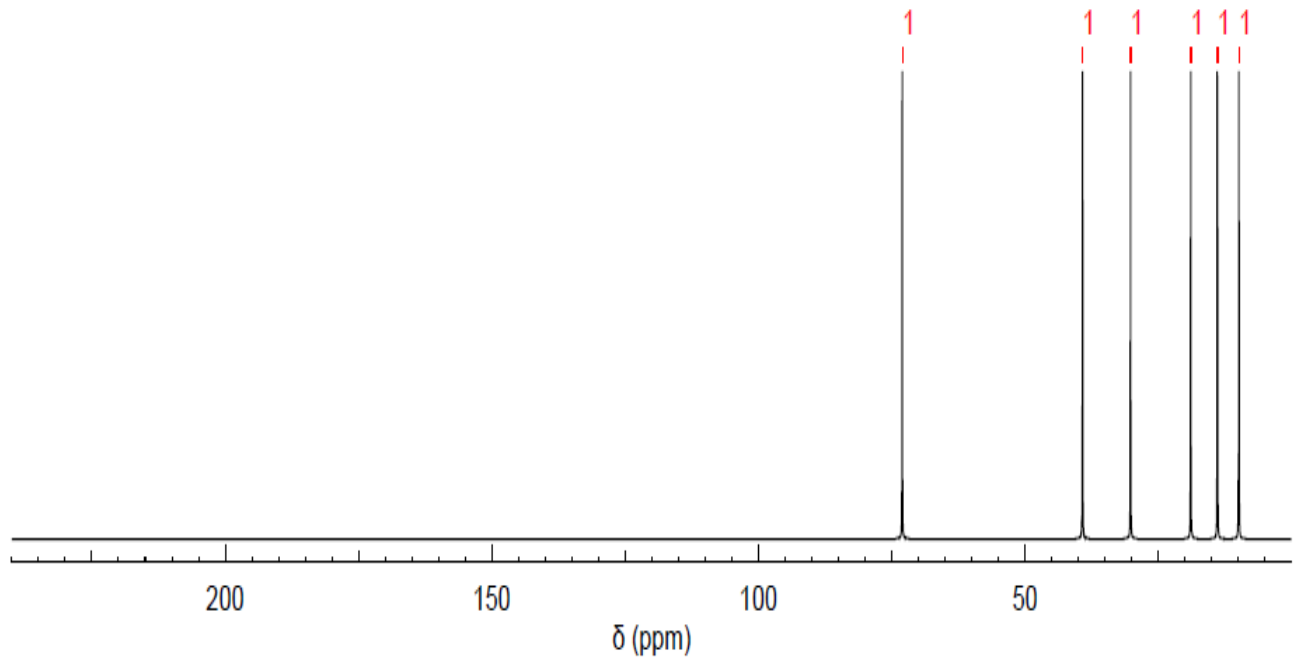

Gambar 7. Spektrum ${ }^{13} \mathrm{C}$-NMR Senyawa 2 berdasarkan prediksi

(https://www.nmrdb.org/new_predictor/index.shtml?v=v2.115.0) 


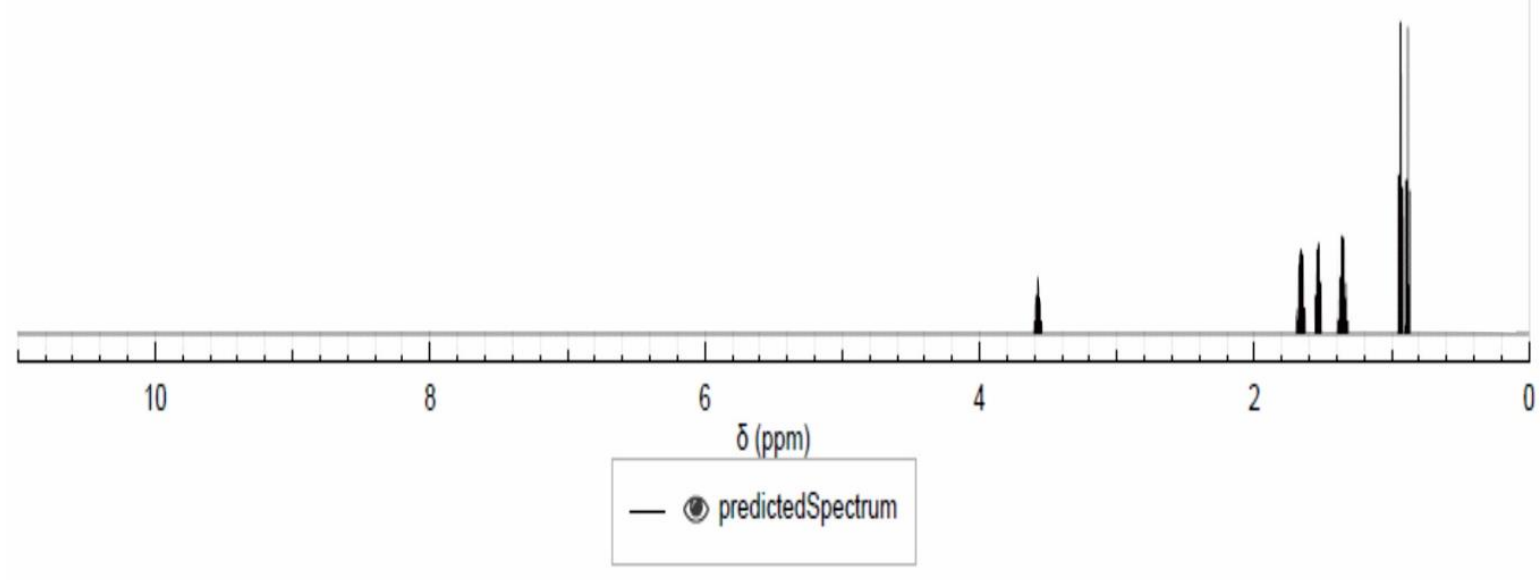

Gambar 8. Spektrum ${ }^{1}$ H-NMR Senyawa 2 berdasarkan prediksi

(https://www.nmrdb.org/new_predictor/index.shtml?v=v2.115.0)

Uji Aktivitas Sitotoksik terhadap sel MCF7 dengan Metode MTT

Pengujian aktivitas sitotoksik dalam penelitian ini menggunakan metode MTT assay (mikrokultur tetrazolium). Metode ini secara prinsip yaitu mengukur aktivitas dehidrogenase mitokondria pada sel-sel hidup yang memiliki kemampuan untuk mengkonversi MTT menjadi formazan.

Hasil aktivitas antikanker ekstrak kulit batang $R$. apiculata dan $R$. mucronata, fraksi n-heksana, fraksi etil asetat dan fraksi etanol secara in vitro pada sel MCF-7 dapat dilihat di Gambar 9.

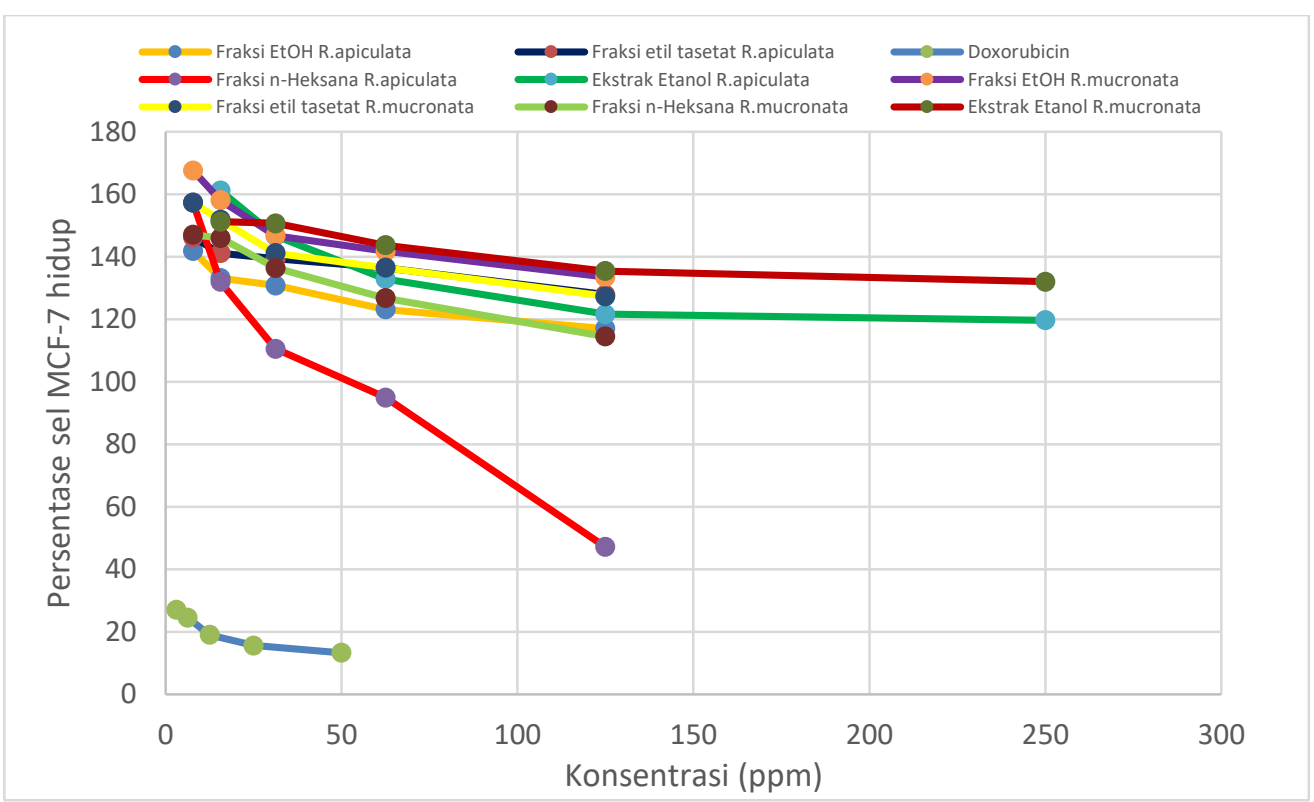

Gambar 9. Grafik persentase sel MCF-7 hidup

Sitotoksisitas sel juga dapat dilakukan kontrol negatif, pemberian sampel dan secara kualitatif dengan pengamatan kontrol positif (doksorubisin) dapat dilihat morfologi sel. Kenampakan sel MCF-7 pada pada gambar 10, menunjukkan morfologi sel 
MCF-7, sel hidup ditandai dengan bentuk epitel dan berwarna terang, sedangkan sel mati ditandai dengan bentuk bulat dan berwarna gelap (tidak bercahaya). Morfologi sel hidup tampak bersinar cemerlang dan batas membran dengan media akan terlihat jelas, sedangkan sel mati tampak bulat, gelap, tidak bercahaya dan membran selnya terlihat pecah atau agak samar.

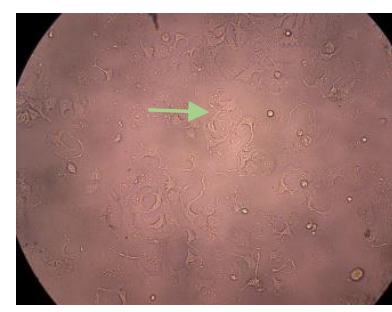

( a )

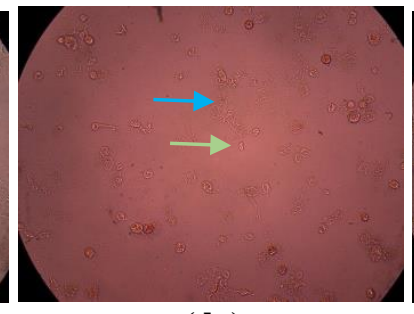

( b )

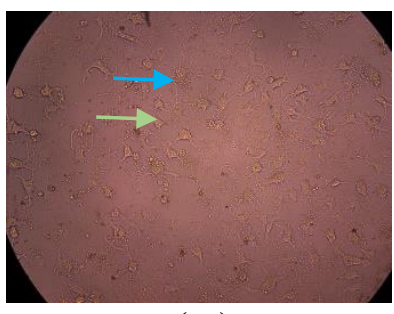

(c)

Gambar 10. Morfologi sel MCF-7 (a) tanpa perlakuan (kontrol negatif), (b) perlakuan dengan doksorubisin (kontrol positif) dan (c) perlakuan dengan sampel fraksi non polar $R$. apiculata $\longrightarrow$ Sel MCF-7 hidup, $\longrightarrow$ Sel MCF-7 mati

Hasil uji aktivitas sitotoksik sampel uji dari ekstrak, fraksi n-heksana, fraksi etil asetat dan fraksi etanol $R$ apiculata dan $R$. mucronata terhadap sel MCF-7 ditunjukkan dengan nilai $\mathrm{IC}_{50}$ sesuai tabel 4. Kontrol positif doxorubicin memiliki kemampuan menginhibisi sel MCF-7 dengan nilai $\mathrm{IC}_{50}$ $4,12 \times 10^{-2} \mu \mathrm{g} / \mathrm{mL}$. menurut National Cancer Institute bahwa nilai $\mathrm{IC}_{50}<30 \mu \mathrm{g} / \mathrm{mL}$ menunjukkan bahwa doksorubisin memiliki aktivitas sitotoksik yang aktif terhadap sel MCF-7.

Tabel 4. Nilai IC 50 sampel uji terhadap sel MCF-7

\begin{tabular}{lcc}
\hline \multicolumn{1}{c}{ Bahan Uji } & IC $\mathbf{5 0}(\boldsymbol{\mu g} / \mathbf{m L})$ & $\begin{array}{c}\text { Keterangan } \\
\text { NCI }\end{array}$ \\
\hline R. apiculata Blume: & $>250$ & Tidak aktif \\
Ekstrak & $>125$ & Tidak aktif \\
Fraksi n-Heksana & $>125$ & Tidak aktif \\
Fraksi Etil asetat & $>125$ & Tidak aktif \\
Fraksi Etanol & & \\
\hline$R$. mucronata Lam: & $>250$ & Tidak aktif \\
Ekstrak & $>125$ & Tidak aktif \\
Fraksi n-Heksana & $>125$ & Tidak aktif \\
Fraksi Etil asetat & $>125$ & Tidak aktif \\
Fraksi Etanol & $4,12 \times 10^{-2}$ & Aktif \\
\hline Doksorubicin &
\end{tabular}

Keterangan:*Potensi antikanker berdasarkan National Cancer Institute (NCI) Amerika, Aktif (IC50<30 $\mu \mathrm{g} / \mathrm{mL})$, moderat aktif $(30 \mu \mathrm{g} / \mathrm{m} \leq \mathrm{C} 50<100 \mu \mathrm{g} / \mathrm{mL})$, tidak aktif $($ IC50 $\geq 100 \mu \mathrm{g} / \mathrm{mL})$

Ekstrak, fraksi n-heksana, fraksi etil asetat, dan fraksi etanol kulit batang $R$. apiculata dan $R$. mucronata tidak memiliki kemampuan menginhibisi sel MCF-7 dengan nilai $\mathrm{IC}_{50}>125 \mu \mathrm{g} / \mathrm{mL}$, menurut NCI bahwa nilai IC $50 \geq 100 \mu \mathrm{g} / \mathrm{mL}$ menunjukkan bahwa semua sampel uji tidak aktif terhadap sel MCF-7
Uji Aktivitas Sitotoksik terhadap sel T47D dengan Metode MTT Hasil aktivitas antikanker ekstrak kulit batang $R$. apiculata dan $R$. mucronata, fraksi n-heksana, etil asetat dan metanol secara in vitro pada sel T47D dapat dilihat di gambar 11. Kenampakan morfologi sel T47D pada kontrol negatif, pemberian sampel dan kontrol positif 
(doksorubisin) menunjukkan morfologi sel T47D sel hidup ditandai dengan bentuk epitel dan berwarna terang, sedangkan sel mati ditandai dengan bentuk epitel tipis dan berwarna gelap (tidak bercahaya), membran selnya terlihat pecah atau agak samar (Gambar 12).

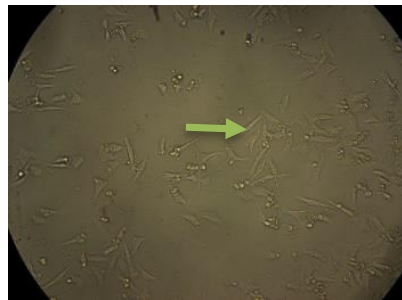

( a )

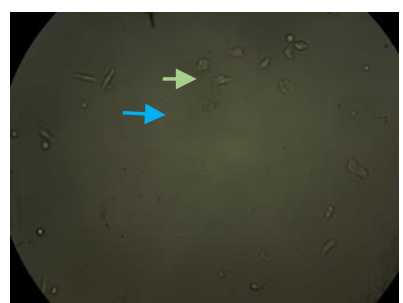

( b )

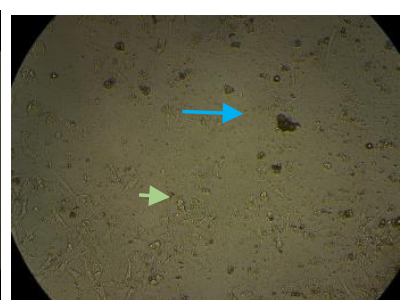

(c)

Gambar 12. Morfologi sel T47D (a) tanpa perlakuan (kontrol negatif), (b) perlakuan dengan doksorubisin (kontrol positif) dan (c) perlakuan dengan sampel fraksi non polar $R$. mucronata $\rightarrow$ Sel T47D hidup, $\rightarrow$ Sel T47D mati

Tabel 5. Nilai IC50 sampel uji terhadap sel T47D

\begin{tabular}{|c|c|c|}
\hline Bahan Uji & $\begin{array}{c}\mathrm{IC}_{50} \\
(\mu \mathrm{g} / \mathrm{mL})\end{array}$ & Keterangan NCI \\
\hline \multicolumn{3}{|l|}{ R. apiculata Blume: } \\
\hline Ekstrak & $>250$ & Tidak aktif \\
\hline Fraksi n-Heksana & $>125$ & Tidak aktif \\
\hline Fraksi Etil asetat & $>125$ & Tidak aktif \\
\hline Fraksi Etanol & $>125$ & Tidak aktif \\
\hline \multicolumn{3}{|l|}{ R. mucronata Lam: } \\
\hline Ekstrak & $>250$ & Tidak aktif \\
\hline Fraksi n-Heksana & $>125$ & Tidak aktif \\
\hline Fraksi Etil asetat & $>125$ & Tidak aktif \\
\hline Fraksi Etanol & $>125$ & Tidak aktif \\
\hline Doksorubicin & $7,50 \times 10^{-1}$ & Aktif \\
\hline
\end{tabular}

Keterangan: *Potensi antikanker berdasarkan National Cancer Institute (NCI) Amerika,

Aktif (IC50<30 $\mu \mathrm{g} / \mathrm{mL})$, moderat aktif $(30 \mu \mathrm{g} / \mathrm{m} \leq$ C50<100 $\mu \mathrm{g} / \mathrm{mL})$, tidak aktif (IC50 $\geq 100 \mu \mathrm{g} / \mathrm{mL})$

Hasil uji aktivitas sitotoksik sampel uji dari ekstrak, fraksi n-heksana, fraksi etil asetat dan fraksi etanol $R$ apiculata dan $R$. mucronata terhadap sel T47D ditunjukan dengan nilai $\mathrm{IC}_{50}$ sesuai Tabel 5. Kontrol positif doxorubicin memiliki kemampuan menginhibisi sel T47D dengan nilai $\mathrm{IC}_{50}$ $7,50 \times 10^{-1} \mu \mathrm{g} / \mathrm{mL}$. Menurut National Cancer Institute bahwa nilai $\mathrm{IC}_{50}<30$ $\mu \mathrm{g} /$ menunjukkan doksorubisin memiliki aktivitas sitotoksik yang aktif terhadap sel T47D. Fraksi n-heksana, fraksi etil asetat, dan fraksi etanol kulit batang $R$. apiculata dan $R$. mucronata tidak memiliki kemampuan menginhibisi sel T47D (nilai $\mathrm{IC}_{50}>125$ $\mu \mathrm{g} / \mathrm{mL}$ ), sedangkan ekstrak memiliki nilai
$\mathrm{IC}_{50}>250 \mu \mathrm{g} / \mathrm{mL}$. Menurut NCI bahwa nilai IC $50 \geq 100 \mu \mathrm{g} / \mathrm{mL}$ menunjukkan bahwa sampel uji tidak aktif terhadap sel T47D.

Nilai IC $_{50}$ ekstrak, fraksi n-heksana, fraksi etil asetat, dan fraksi etanol kulit batang $R$. apiculata dan $R$. mucronata sesuai dengan standar National Cancer Institute (NCI) Amerika yang menyatakan bahwa standar efektivitas komponen bioaktif untuk melawan sel kanker harus lebih rendah dari $30 \mu \mathrm{g} / \mathrm{mL}$. Dengan nilai $\mathrm{IC}_{50}$ yang sangat tinggi, maka ekstrak, fraksi n-heksana, fraksi etil asetat, dan fraksi etanol kulit batang $R$. apiculata dan $R$. mucronata tidak memiliki potensi untuk dikembangkan lebih lanjut sebagai agen antikanker sel MCF-7 dan T47D. 


\section{KESIMPULAN}

Hasil isolasi dari fraksi etil asetat ekstrak etanol kulit batang $R$. mucronata diperoleh senyawa $n$-heksan-3-ol.

Ekstrak etanol kulit batang $R$. apiculata yang difraksinasi dengan etil asetat dan diisolasi dengan n-heksana:etil asetat (5:5) diperoleh senyawa cis-3-(3,5-dihidroksifenil) akrilik acid.

Ekstrak etanol, fraksi n-heksana, fraksi etil asetat dan fraksi etanol kulit batang $R$. mucronata dan $R$. apiculata berdasarkan aktivitas sitotoksik tidak aktif terhadap sel T47D dan sel MCF-7

\section{Daftar Pustaka}

Atun, S. 2014. Metode isolasi dan identifikasi struktur senyawa organik bahan alam, Jurnal Konservasi Cagar Budaya Borobudur, Volume 8, Nomor 2, Desember 2014, Hal 53-61

Backer, C.A., \& Van DenBrink, B.R.C.1963. Flora of Java (Spermatophytes Only) Vol I, N.V.P. Noordhoff, Groningen

Bandaranayake, M. 2002. Bioactivities, bioactive compounds and chemical constituents of mangrove plants, Wetlands Ecology and Management 10 (6): 421-452

Berawi, K.N., dan Marini, D. 2018. Efektivitas kulit batang bakau minyak (Rhizopora apiculata) sebagai antioksidan, Agromedicine, Volume 5, Nomor 1, Juni 2018

CCRC. 2009. Prosedur tetap uji sitotoksik metode MTT, Cancer chemoprevention research center Farmasi UGM Yogyakarta, 6-9.

CCRC. 2014. Sel MCF-7, Terdapat di:http://ccrc.farmasi.ugm.ac.id/?page_id=1234 [Diakses pada 24 Januari 2020].

CCRC. 2014. Sel T47D, Terdapat di:http://ccrc.farmasi.ugm.ac.id/?page_id=1239 [Diakses pada 24 Januari 2020].

Diastuti, H., Warsinah, dan Purwati. 2008. Uji aktivitas antikanker ekstrak etanol daun Rhizopora mucronata terhadap sel myeloma, Molekul, Vol. 3. No. 2. Nov, 2008: 63-70

Gerothanassis, I. P., Troganis, A., Exarchou, V., \& Barbarossou, K. 2002. Nuclear magnetic resonance (NMR) spectroscopy: basic principles and phenomena, and their applications to chemistry, biology and medicine. Chemistry Education Research and Practice, 3(2), 229-252.

Hadiyati, T. 2000. Zonasi mangrove pada daerah akresi dan non akresi di Segara Anakan Cilacap, Biosfera, A Scientific Journal. Vol 17

Harwoko dan Utami, D.E. 2010, Aktivitas sitotoksik fraksi n-heksanaloroform dari ekstrak metanol kulit batang mangrove (Rhizopora mucronata) pada sel kanker myeloma, Majalah Obat Tradisional, 15(2), $51-55$

https://www.kemkes.go.id/article/view/19020100003/hari-kanker-sedunia-2019.html https://www.nmrdb.org/new_predictor/index.shtml?v=v2.115.0

Jones, I. C., Sharman, G. J., \& Pidgeon, J. 2005. 1H and 13C NMR data to aid the identification and quantification of residual solvents by NMR spectroscopy. Magnetic Resonance in Chemistry, 43(6), 497-509.

Koyama, Y., Hosomi, M., Hashimoto, H., \& Shimamura, T. 1989. 1H NMR spectra of the alltrans, 7-cis, 9-cis, 13-cis and 15-cis isomers of $\beta$-carotene: elongation of the double bond and shortening of the single bond toward the center of the conjugated chain as revealed by vicinal coupling constants. Journal of Molecular Structure, 193, 185-201.

Ma'at, S. 2003. Tanaman obat untuk pengobatan kanker, Jurnal Bahan Alam Indonesia 
Machana, S, Weerapreeyakul, N., Barusrux, S., Nonpunya, A., Sripanidkulchai, B., Thitimetharoch, T. 2011. Cytotoxic and apoptotic effects of six herbal plants against the human hepatocarcinoma (HepG2) cell line. Chinese Medical Journal. 6(39): 1-8.

McMurry, J. E. 2010. Fundamentals of organic chemistry. Cengage Learning.

Mingzhe Gao and Hongbin Xiao 2012, Activity-Guided isolation of antioxidant compounds from Rhizophora apiculata, 17, 10675-10682; doi:10.3390/molecules 170910675 www.mdpi.com/journal/molecules, Article, Molecules

Nerantzaki, A. A., Tsiafoulis, C. G., Charisiadis, P., Kontogianni, V. G., \& Gerothanassis, I. P. 2011. Novel determination of the total phenolic content in crude plant extracts by the use of 1H NMR of the-OH spectral region. Analytica chimica acta, 688(1), 54-60.

Noor, R.Y., Khazali, M., dan Suryadiputra, I.N.N. 2006. Panduan pengenalan mangrove di Indonesia. PHKA/WI-IP, Bogor.

Pavia, D. L., Lampman, G. M., Kriz, G. S., \& Vyvyan, J. A. (2008). Introduction to spectroscopy. Cengage Learning.

Rahim, A.A., Rocca, E., Steinmetz, J., Kassim, M.J. 2008. Antioxidant activities of mangrove Rhizophora apiculata bark extracts, Food chemistry, 200-27, American Cancer Society, 2017

Rajendra B Kakde, 2011, Cancer therapeutics opportunities, challenges and advances in drug delivery, Journal of Applied Pharmaceutical Science I (9): 1-10

Sastrohamidjojo, H. 2005. Kromatografi. Yogyakarta: Penerbit Liberty

Sastrohamidjojo, H. 2007. Spektroskopi. Yogyakarta: Penerbit Liberty

Soetarno, S. 2000. Potensi dan manfaat tumbuhan mangrove sebagai sumber bahan bioaktif, ActaPharmaceutica Indonesia, 12 (4): 84- 103.

Sudjarwo, G.W., Mahmiah, Hukmiyah, M, 2017, Kandungan senyawa metabolit sekunder dari fraksi etil asetat kulit batang Rhizopora muronata L., Seminar Nasional Kelautan XII

Ward, R. L. 1999. A complete introduction to modern NMR spectroscopy. Macomber, Rodger S. 